\title{
Contrastive Analysis on Discourse Strategies News about Islamophobic (Islamfeindlichkeit) and Antisemitism (Judenfeindlichkeit) in German Online Newspaper
}

\author{
Ajeng Dianing Kartika \\ Universitas Negeri Surabaya \\ Surabaya, Indonesia \\ ajengkartika@unesa.ac.id
}

\author{
Lutfi Saksono \\ Universitas Negeri Surabaya \\ Surabaya, Indonesia \\ lutfisaksono@unesa.ac.id
}

\begin{abstract}
Islamophobic and Antisemitism have become trending topics in Germany nowadays. The rise of Muslims population in Germany during migration crisis that cause pro and contra in society can be the main cause of the Islamophobic in the country lead by Angela Merkel. On the other side, there is another phenomenon called anti-Semitism that has historically occurred since Nazi's era. Currently, this phenomenon suddenly rises up during migration crisis and it has been strongly discussed after the controversy created by duo rappers Kollegah (Felix Blume) and Farid Bang (Farid El Abdellaoui) who took home the prize for their anti-semitism songs in album Jung, Brutal, Gutaussehend 3. Pros and cons appear and they become trending topic in German online newspaper along with the islamophobia that's still debatable. Even though these two phenomena have one similiarity, namely 'anxiety feeling or extreme fear of something', there are different strategies used by the Press in Germany. Crictical analysis is needed to reveal specific strategies applied and the impact of the kind of strategies on the representation of Muslims and Jews in Germany. Based on critical discourse studies, it can be concluded that the German online newspaper defines Islam as outer group who creates islamophobic. But, Jews are represented differently as a victim of anti-Semitism.
\end{abstract}

Keywords—islamophobic; antisemitism; critical discourse analysis

\section{INTRODUCTION}

Jews and Muslims occupy different positions in European perception since a long time. The argument of a JewishChristian West, which is appealed to political and media debates in demarcation to Is lam. Because for centuries the Jews and Islam were considered as Europe's "Other." Muslims have been against it since the Middle Ages rather perceived as an external enemy. Only with the postcolonial migration to test Europe and the recruitment of live foreign workers through the Federal Republic Muslim minorities here in greater numbers and have the Position of the "Other" inside taken.

Modern antisemitism, as it took shape in 19th century Germany, arose not least as a hostile reaction to emancipation, the legal enfranchisement and increased social mobility enjoyed by members of the Jewish minority. The debate surrounding Islam in Europe today may likewise be explained in part by the increased participation of Muslims in broader society. It is generally not the backyard mosques that elicit a hostile response, it is the more prominent and ornate houses of worship which are visible in the urban landscape and which shows Muslims as members of European society. One further parallel to the 19th century debate is that Jews were accused of separating themselves from the mainstreamculture on account of their religion. They were even believed to harbor hostile feelings against the majority, refusing to integrate and holding no loyalty to the State [1].

Such prejudices are also evident in the debate over Islam today. In academic circles, it has been suggested that cultural racism against Muslims serves a similar function in the process of European integration as that served by antisemitism in the formation of the European nation states in the 19th century. In both cases, it begins with a phase of accelerating social changes which appear to threaten the established social order and lead to starker divisions between "us" and the alleged foreigner. The invocation of an "occidental" identity thus serves to stabilize the constructs of national identity, as the debate over a "leading culture" (Leitkultur), which repeatedly flares up in Germany, demonstrates. Such debates are often launched with the assertion that Islam is fundamentally incompatible with "Western culture." This claim has significant resonance within the world views of the majority population: according to representative surveys, approximately 39olo of all Germans would agree with the statement "with so many Muslims around, I often feel like a foreigner in my own country."' The fear of being overrun by foreigners and alienated in one's own land implies that being Muslim and being European or German are opposing and incompatible identities-i.e., that a Muslim cannot be a "proper" European or German. This questioning of belonging in the national sense-which is tantamount to rhetorical denaturalization-is a familiar theme from the history of German antisemitism in the 19th century, which many German Jews are still confronted with today. The former 
Chairman of the Zentralrat der Juden in Germany, lgnatz Bubis, for instance, was once congratulated during a state visit by the ls raeli President Weizman upon the successfulspeech of "his" president. Anti-Muslim racism thus shares with antisemitis $m$ a categorization of its objects using both religious and ethnic criteria, and identifies them with a transnational collective. Structural analogies between anti-lslamic and antisemitic discourses also appear in the rhetorical use of religious texts. Just as anti-Muslim pundits today like to support their allegatlons with references to the Koran, antisemitic pamphlets of the 19th century used similar arguments when referring to the Talmud.' There are also often parallels in the conclusions that hostile readers draw from the Talmud and the Koran.

Nowadays the German's trends of anti-Semitism and islamophobia develop in different ways. The statistic taken from Suddeutsche Zeitung stated that the islamophobia has risen in this country, namely since the entering of myriad migrants from muslim countries. The migration crise that has occurred since 2013 has caused contentions. Pro and contra within the german about the existence of the muslim migrants has been a significant themes in mass media. Some people label the migrants as 'threat' for Germany but not least from the germans feel sorry for them since they have to move from their country, that still in a state of war. In the other side Antisemitism which is already forgotten has suddenly come up as a hot news in Germany during migration crise. After refugee influx it is reported by The Washington Post that there were 947 incidents of anti-Semitic attacks, threats and vandalism in the city in 2017 - almost double the number from the previous year.

Focusing on the existence of anti-Semitism within the rise of is lamophobia during migration crises as a case study and by applying methodological tools such as critical discourse analyses, the construction, representation, and denunciation of these notions in media will be examined. Media has always been a powerful and influential tool to disseminate knowledge in the society. One of its influences has to do with how society creates knowledge of situations through presentation. The media is a tool which has the power to affect people's opinions and beliefs; they have the power to produce 'knowledge' through facts and fictions by deciding on what people ought to focus their attention on.

\section{LITERATURE REVIEW}

The main task of critical discourse analys is is to reveal the power relations, dominance and inequality produced in discourse [2]. The critical word implies a deeper study of the idea implicitly conceived by a discourse. Conducting critical discourse reviews requires us to discover the ideas underlying the production of discourse. Agreed with van Dijk, Renkema stated that discourse is a reflection of power relations contained in society [3]. He said the critical discourse review was conducted with the aim to detect social and political problems that occur in society, especially the problem of discrimination. Critical discourse studies place language as a means of manifesting the power of certain parties. In addition language is also a means of ideological battle for discourse to legalize its power.
Freeden in Fairclough explains that the concept of ideology in its development is widely used especially in the realm of contemporary political science with a more specific concept, for example ideology is used to denote the political beliefs of certain groups [4]. In practice ideology as a political belief of a particular group is often used as a basis for legitimating abuse of power committed by dominant groups. In the study of critical discourse ideology relates to the foundation used in the process of discourse production. Language as Ideology reveals that ideology is a systematic form of ideas produced through a particular view that influences the process of discourse production. In more detail, in his article entitled Politics, Ideology and Discourse, Van Dijk explains that ideology is produced through cognitive and social processes [5]. From a cognitive point of view, ideology is a belief system stored in long-term memory. Ideology is not individual but social. The belief system that an individual possesses is influenced by his or her social environment. Ideology becomes a basic belief that belongs to a group and is shared by all members of the group. Ideology becomes the foundation of a group in representing the existing social phenomena. Discourse becomes a means to convey the social phenomenon that is happening to the community. The ideology of discourse-producing parties will influence how social phenomena are realized in discourse through language.

\section{A. Ideology and Discourse Production}

Discourse, especially political discourse, cannot be separated from the ideology that compiles it. The writer's Ideology, in this research journalist, plays an important role in the process of discourse production. Ideology as a 'system of ideas' is interpreted socio cognitively as a representation shared by a social group and more specifically defined as the axiomatic principle underlying that representation. Therefore ideology is social. Ideology organizes and controls communication among members of social groups with each other, how they should act and respond to certain issues in society [1].

Ideology in discourse is manifested through the form of polarization Us-Them. Overall, in the discourse, the author's polarization through the positive presentation / action of Us strategy and the negative presentation / action of Them (negative description of them) is done in 2 ways, namely emphasize Our good things and Their bad things (emphasizing the good of us and the bad things of them) and de-emphasize Our bad things and Their good things [5]. The ideology conceived of a discourse can be studied systematically by analyzing how members of the same group emphasize the good deeds of the group and other bad deeds of the group and deny the bad deeds of the group and the good deeds of other groups. Ideology is expressed in discourse at the level of meaning, form, and action.

\section{B. Discourse, Social Practice and Subject Representation}

Subjects are created in discourse [6]. The argument 'the death of the subject' is 'that people are not really free to think and act, because they - and their ideas and activities - are produced by the structures (social, political, cultural) in which they live'. It is also stated that 'The self no longer uses language (discourse) to express itself; rather language speaks 
through the person [7]. The individual self becomes a medium for the culture and its language. It is discourse, not the subject who speak it, which produces knowledge. Subjects may produce particular texts, but they are operating within the limits of the episteme, the discursive formation, the regime of truth, of a particular period and culture [4]. This subject of discourse 'cannot be outside discourse, because it must be subjected to discourse. It must submit to its rules and conventions, to its dispositions of power/knowledge. The subject can become the bearer of the kind of knowledge which discourse produces. It can become the object through which power is relayed. But it cannot stand outside power/knowledge as its source and author.'

Therefore, it is stated that subject in discourse that he tends to mention it as 'social actors' are represented during the discourse production [8]. Discourse works as a social practice in which the social environment surround can directly affect it. There is polarization us -them or in group - out group that mark the relation of the social actor in discourse. In group tends to describe in a positive way rather than out group, which are not a part of the writer and described in negative way.

\section{Discourse Elements}

To reveal the representation of social actors in discourse we have to analyse both linguistics and non-linguistics, such history, politics, and culture that form the texts. Van Dijk has classified discourse into three elements, namely text, context, and social cognition [8]. Text is divided into 3 structures, specifically macro structure, super structure, and micro structure to reach the goal of the analysis. The macro element refers to the global topic of discourse. The global topics that are meant here are often misconstrued by the title. The reader often assumes that the title already represents a global topic of discourse. Van Dijk, however, argued differently. The title is only one of the schematic elements of the discourse that delivers the reader to know the contents of the discourse. The global topic he means is the essence of the whole discourse built through the coherent relationship of macro-discourse propositions. Proposition of macro discourse is obtained through macro rules consisting of deletion, generalization, and construction.

The global topic of discourse can be found not only through the thematic discourse, but also the schematic discourse also called superstructure [9]. Schematic text news discourse refers to two major schemes, namely summary (conclusion) and story (story). The conclusions are marked by the presence of headline elements (headings) and leads (the news terrace). Title and news terrace is a big conclusion the overall content of the news text. Therefore, the information contained in both plays an important role, namely as an initial provision for the reader to be able to understand the information submitted to the whole text of the news.

The second scheme is a story marked with verbal reactions (verbal reactions). In the news text verbal reactions are realized through comments (comments). Comments in the news text can be comments from actors related to events, outsiders who are experts, as well as personal comments of journalists implicitly listed in the discourse. The comments in the news text are classified into 2, namely the comments in the form of evaluation (evaluation) and expectation (expectations). Comments in the form of evaluation is an assessment of events that occur in a discourse. On the other hand, comments in the form of expectations are predictions or predictions about an event and the sustainability of the event in the future [9]. The selection of comments included in a news indicates the tendency of the compiler of the news text. The reader as a discourse interpreter should observe further the background or profile of a person or person who commented on a particular message to know the trend. The intended tendency relates to the possibility of the alignment of news connoisseurs on the engagement of certain discourses.

In the process of analyzing the global topic of political discourse, Van Dijk classifies the four main categories of discourse events, ie causes, political situations, antecedents, and consequences [9]. The three categories are thematic structures derived from macro propositions that ultimately build the main events of discourse. The main events will later be tied to the discourse schematic to find the global topic of discourse. The global topic of discourse is built by the interrelationship between events. The linguistics between categories of events are related to each other and are coherent. The occurrence of an event according to Van Dijk must have an introduction that gives rise to certain consequences. An event occurs also because of certain causes built by a particular political situation. Keep in mind that the composition of the main constituent categories in the discourse is not absolute, but is flexible because each discourse has a difference in terms of presentation.

After doing the analysis on the macro level of discourse. The microstructure distinguishes between the meaning and the form of its realization on the surface structure of the discourse such as words, phrases, clauses, and sentence forms. The local meaning of discourse can be seen through micro propositions as the smallest unit of meaning of a sentence. In accordance with the opinion of Van Dijk things that affect the local meaning of discourse related to the ideology contained in the discourse among others, such as Local coherence, Discourse manifestation, Granularity, Modality, Lexical choices, Syntactical choices, Argumentation, Disclaimer, Presupposition and entailment. [9].

The second and the third elements that are formed the discourse are social cognition and context. Van Dijk also asserts that the context cannot be called an objective construction of the social environment surrounding the discourse, but the subjective construction of participants about social property relevant to a particular situation based on the social environment in which they live [8]. This process is controlled by a mental model or a participant's situation model. The context of the model, a context constructed by the mental model, is a special model of daily experience that is represented in the episodic memory of discourse participants. The model context controls the production process and discourse understanding. Participants are not only involved in the production of discourse technically, at the same time they are also involved in the process of constructing their mental models in analyzing and interpreting the communicative situations that occur in the discourse. 
The mental model forms the basis of semantic representation of discourse. The mental model is the cognitive representation of participants' experience of discourse stored in episodic memory, which is part of their long-term memory. Discourse will be meaningful if the discourse has a model. A series of sentences in the discourse can be said to be coherent if participants are able to build a mental model of the events they hear, read, talk about, and write and relate the facts that make up the event [8]. Being subjective, the mental model not only represents the fact of an event entirely as seen by discourse participants but also involves their opinions and emotions in dealing with the related event. The formation of the mental model is subjective and is influenced by the experience and knowledge shared by the discourse participants. This experience and knowledge will affect the participants' goals and beliefs in producing discourse. On the other hand knowledge is processed in semantic memory of discourse participants. Both are related to each other. For example, when compiling a discourse on the Iraq War, a journalist as a discourse participant will shape or update the mental model of this event and this process of formation or renewal utilizes the journalist's knowledge of soldiers, weapons, war victims and other as pects of war.

Based on the description it can be concluded that the discourse is produced and interpreted individually by participants, in this study journalists. However, journalists are only able to produce and interpret the discourse in accordance with the basis of experience and knowledge possessed and shared by the social group where it resides. These experiences and knowledge shape the social beliefs that journalists have about a particular is sue or entity. Simultaneously discourse can only affect the social situation through the mental model of journalists, otherwise the social situation can only affect discourse through the mental model of journalists. The mental model consists of a model of context and an event model. Context models operate control in discourse processing, ie keeping the intent and purpose of discourse production. The context model explains social relationships among participants and the social situation that surrounds them [5]. The context model filters out the relevant representations generated by the event model. So it can be observed that the reciprocal relationship between discourse and journalist as a discourse participant is connected by the knowledge and experience of the journalist forming his mental model of the particular entity being discussed.

\section{DISCUSSION}

The term "Is lamophobia" was originally contrived as a notion by politician in the late 1990s to focus on rhetorical functions, actions, and manners towards Islam and the Muslim communities in the West. This word consists of two parts, namely "Islam" (the religion of Muslims) and "phobia" which is defined by the Oxford Dictionary (2005) as "a strong unreasonable fear or hatred of a particular thing". The notion has been defined by some researchers differently: Islamophobia is defined as "fear of Muslims and the Islamic faith" or "the fear or dread of Islam or Muslims." In one of the most carefully considered definitions, in states that "Islamophobia is a rejection of Islam, Muslim groups and
Muslim individuals based on prejudice and stereotypes. It may have emotional, cognitive, evaluative as well as action-oriented elements (e.g. discrimination, violence).

In another hand there is a phobia that involve different subject called anti-Semitism. 4 news about Islamophobia and anti-Semitism from the right conservative newspaper Die Welt during 2018 below are chosen for this study:

a. https://www.welt.de/politik/deutschland/article178494 258/Radikalisierung-Studie-entdecktGemeins amkeiten-zwischen-Islamisten-undNeonazis.html?wtrid=onsite.onsitesearch

b. https://www.welt.de/politik/deutschland/article174861 632/Kretschmer-ueber-radikale-Muslime-Wirerleben-ein-neues$\underline{\text { Kriminalitaetsphaenomen.html?wtrid=onsite.onsitesea }}$ $\underline{\mathrm{rch}}$

c. https://www.welt.de/regionales/sachsenanhalt/article 176891925/Haseloff-warnt-vor-neuemAntisemitis mus.html?wtrid=onsite.onsites earch

d. https://www.welt.de/debatte/kommentare/article17694 0885/Antisemitis mus-Fluechtlinge-undIsrael.html?wtrid=onsite.onsites earch

From those 6 news there is 2 global topis found. The first is Islam is radical and the second is anti-Semitism occurs because of the existence of moslem in Europe. This topics are generated through macro strategies deletion and generalization. These strategies are applied as follows:

( ${ }^{\text {st }}$ paragraph) Für Sachsens Ministerpräsident Kretschmer gehörten bestimmte Muslime nicht zu Deutschland (1). Erverstehe den FliichtlingsAufnahmestopp einiger Kommmen(2). An Städtwie Cotbus sehe man, ,es gibtein Problem, was die Integration angeht" [3].

The deletion of the sentences 2 and 3 are done to find out the macro proposition in the first paragraph, namely the opinion of Sachsen's Minister President that stated the position of moslem as a different part of Germany.

Another macro rule applied in this case is generalization. The proposition, that have same meaning can be generalized in such a way:

( $1^{\text {st }}$ paragraph) Für eine Studie wurden zwischen 2013 und 2017 mehr als 10.000 extremistische Posts in sozialen Medien untersucht (1). Das Ergebnis: Islam isten und Neonazis haben viel gemeinsam (2). Allerdings sei die Rhetorik der Islamisten , ,deutlich gemäßigter“ (3) (Data 2)

From the paragraph above it can be observed that the proposition in sentence 1-3 lead us to the same purpose to show that Islam and Neo Nazism have many similarities although Islam has more moderate rhetoric. The journalist try to equate the characteristic of Islam and Neo Nazism, namely bring up anti-Semitis $m$ and militant. This happens because the journalist come from and live in Germany, in which they have got experience and knowledge about Neo Nazism. It's the social cognition the journalist have that affect their point of view. From the 4 data it can be found macro propositions below: 
TABLE I. MACRO PROPOSITIONS

\begin{tabular}{|c|c|}
\hline \multirow{6}{*}{$\begin{array}{l}\text { DATA 1 } \\
\text { Studie entdeckt } \\
\text { Gemeinsamkeiten zwischen } \\
\text { Islamisten und Neonazis }\end{array}$} & $\begin{array}{l}\text { Eine Studie zeigt, dass Islamisten und } \\
\text { Neonazis haben viel gemein }\end{array}$ \\
\hline & $\begin{array}{l}\text { Feindlichkeit gegen Muslime und Islamismus } \\
\text { ist radikaler und verbreiteter als Neonazis }\end{array}$ \\
\hline & $\begin{array}{l}\text { Institut für Demokratie undZivilgesellschaft } \\
\text { hat von 2013-2017 eine Studiem it dem } \\
\text { Thema „Hassliebe: Islamfeindlichkeit, } \\
\text { Islamismus und die Spirale } \\
\text { gesellschaftlicher Polarisierung“ gemacht }\end{array}$ \\
\hline & $\begin{array}{l}\text { Islamismus und Rechtsextremismus treffen } \\
\text { sich den Wissen schaftlern zufolge } \\
\text { ideologisch im Antisemitismus, in } \\
\text { Verschwörung smythen und im Ziel } \\
\text { homogener Gesellschaften }\end{array}$ \\
\hline & $\begin{array}{l}\text { islamistische Kommunikation in den sozialen } \\
\text { Netzwerken stark eingeschränkt und ihre } \\
\text { Rhetorik,,deutlich gemäßigter" als noch } \\
\text { Anfang } 2017 \text { sei }\end{array}$ \\
\hline & $\begin{array}{l}\text { Islamistische Radikalisierung, } \\
\text { antimuslimischer Rassismus und } \\
\text { Antisemitismus müssen zusammen gedacht } \\
\text { werden }\end{array}$ \\
\hline \multirow[t]{8}{*}{$\begin{array}{l}\text { DATA } 2 \\
\text { „Wir erleben ein neues } \\
\text { Kriminalitätsphänomen“" }\end{array}$} & $\begin{array}{l}\text { FürSachsens Ministerpräsident Kretschmer } \\
\text { gehörten bestimmte Muslime nicht zu } \\
\text { Deutschland }\end{array}$ \\
\hline & $\begin{array}{l}\text { Der Regierungschef zeigte Verständnis für } \\
\text { Kommunen, die so wie das sächsische } \\
\text { Freiberg oder Cottbus in Brandenburg keine } \\
\text { Flüchtlinge mehr aufnehmen wollen }\end{array}$ \\
\hline & $\begin{array}{l}\text { Es gibt objektiv ein Problem, was die } \\
\text { Integrationangeht. Es fehlen beispielsweise } \\
\text { Plätze in Kindergärten und Schulen. Und es } \\
\text { gibt Probleme mit Menschen, die sich nicht } \\
\text { an unsere Werte und Gesetze halten wollen }\end{array}$ \\
\hline & $\begin{array}{l}\text { jugendliche Migranten in größeren Gruppen } \\
\text { auftreten und sich von normaler Ansprache } \\
\text { nicht beeindrucken lassen }\end{array}$ \\
\hline & $\begin{array}{l}\text { Wir erleben ein } \quad \text { neues } \\
\text { Kriminalitätsphänomen. UndAbschiebungen } \\
\text { funktionieren nicht, weil Flüchtlinge ihre } \\
\text { Identität verschleiern }\end{array}$ \\
\hline & $\begin{array}{l}\text { Horst Seehofer will das Land nicht spalten, } \\
\text { sondern wieder zusammenführen }\end{array}$ \\
\hline & $\begin{array}{l}\text { das Integrations-Leitbild, das wir haben } \\
\text { müssen, das muss basieren auf den } \\
\text { republikanischen Werten des Grundgesetzes, } \\
\text { aufunserer Rechtsordnung, und fürdie kann } \\
\text { es keinen Rabatt geben für niemanden }\end{array}$ \\
\hline & $\begin{array}{l}\text { Generalsekretär des Zentralrats der } \\
\text { Muslime findet, dass Die erneute Debatte } \\
\text { der Islamfeindlichkeit wollen die } \\
\text { Gesellschaft spalten }\end{array}$ \\
\hline \multirow[t]{3}{*}{$\begin{array}{l}\text { DATA } 3 \\
\text { Haseloff warnt vor neuem } \\
\text { Antisemitismus }\end{array}$} & $\begin{array}{l}\text { Jegliche Form von Antisemitismus - von } \\
\text { rechts wie von links - wird in unserer } \\
\text { Gesellschaft nicht geduldet }\end{array}$ \\
\hline & $\begin{array}{l}\text { Haseloffhatte betont, dass es wichtig ist, der } \\
\text { Ausbau der Kontakte mit Israel in } \\
\text { Wirtschaft, Wissenschaft, Sport und Kultur } \\
\text { sei }\end{array}$ \\
\hline & $\begin{array}{l}\text { Laut dem Bundesinnenministerium sind im } \\
\text { vergangenen Jahr bundesweit rund } 1500 \\
\text { antisemitische Delikte erfasst worden }\end{array}$ \\
\hline \multirow{4}{*}{$\begin{array}{l}\text { DATA } 4 \\
\text { Jeder Flüchtling sollte ein } \\
\text { Bekenntnis zu Israel } \\
\text { unterschreiben }\end{array}$} & $\begin{array}{l}\text { Importierte Antisemitismus passiert in } \\
\text { Deutschland }\end{array}$ \\
\hline & $\begin{array}{l}\text { Zuwanderung ist eine Ursache importierte } \\
\text { Antisemitismus }\end{array}$ \\
\hline & $\begin{array}{l}\text { MehrMuslime bedeuten nicht automatisch } \\
\text { mehr Antisemitismus. }\end{array}$ \\
\hline & $\begin{array}{l}\text { Die Juden verwirrt sich, wie Deutschland } \\
\text { angesichts seiner Vergangenheit Millionen }\end{array}$ \\
\hline
\end{tabular}

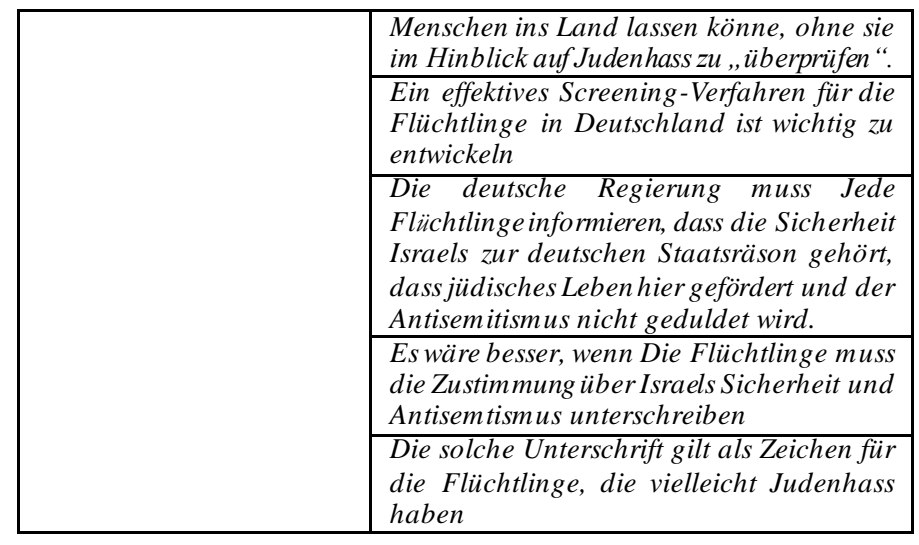

From the macro proposotions above it can be obtained global topics of the datas, namely (1) Islamisten und Neonazis haben viel gemein, (2) Flüchtlinge, die meiste Muslim sind, verursacht neue Kriminalitätsprobleme, (3) Is arels Sicherheit ist für Deutschland wichtig, and (4) Wegen der Zuwanderung passiert heute in Deutschland importierte Antisemitismus. As Van Dijk stated the global topics are affected by social cognition of the journalist [8]. On the other hand this social cognition depends on the social context around that lately form the mental models. Then this mental models is the tool that establish the representation of the meaning of a text. As a language user, the journalist construct mental models of the events texts are about. As a part of German citizens, the mental models of the journalist about Islamfeindlichkeit and Antisemitismus have been formed based on their daily experience and the belief that surround them. Germany and antisemtism has a long history, starting at the Hitlers Era, in which Jews are killed mercilessly. After this passed, Germany felt sorry for the jewa. Therfore this country has tried hard to make amends by the way it concern of Jews security. Although nowadays there is a war between Israel (as Jews country) and Palestine that cause bloodshed and harm to the Muslims in Palestine, in a fact it can be a justifier of the new Antisemitism in Germany.

The idea of global topics in macro structure are supported by the choice of comments the journalist put in the news. The choice of whose comments worth choosing is one of strategies apply in the critical discourse analysis to show the position of the writer, in this case the journalist. The journalist of the WELT choose the comments stated by the experts to convince the reader that the informations they share is accurate. Such comments have also potential rule to direct the reader's perspective. Here's the comments found in the datas that choosen by the journalist of WELT :

- "Extreme Rechte und Islamisten lehnen Freiheit, Pluralismus und Liberalismus ab", erklärte

\section{Studienautor Maik Fielitz}

- Die Londoner Extremismusexpertin Julia Foner hob mit Blick auf die Studienergebnisse zudem hervor, dass islamistische Kommunikation in den sozialen Netzwerken stark eingeschränkt und ihre Rhetorik „deutlich gemäßigter“ als noch Anfang 2017 sei 
- "Islamistische Radikalisierung, antimuslimischer Rassismus und Antisemitismus müssen zusammen gedacht werden", erklärte Reinfrank

- Nach Ansicht des sächsischen Ministerpräsidenten Michael Kretschmer (CDU) gehören bestimmte Muslime nicht zu Deutschland

- Denjenigen, die ,ihre Religion über das Grundgesetz stellen, muss man klarmachen: So kann man nicht in Deutschland leben“, sagte er den Zeitungen der Funke Mediengruppe.

- "Es gibt objektiv ein Problem, was die Integration angeht. Es fehlen beispielsweise Plätze in Kindergärten und Schulen. Und es gibt Probleme mit Menschen, die sich nicht an unsere Werte und Gesetze halten wollen."

- "Es gibt Entwicklungen, vor denen wir nicht zurückschrecken dürfen: Wir erleben ein neues Kriminalitätsphänomen. Und Abschiebungen funktionieren nicht, weil Flüchtlinge ihre Identität vers chleiern."

- "Alle in Deutschland lebenden Menschen müssen wissen: Jegliche Form von Antisemitismus - von rechts wie von links - wird in unserer Gesellschaft nicht geduldet", sagte der CDU-Politiker (SachsenAnhalts Ministerpräsident Reiner Haseloff)

- Der Parlamentarische Staatssekretär im Bundesinnenministerium, Stephan Mayer (CSU), beteuerte: "Horst Seehofer will das Land nicht spalten, sondern wieder zusammenführen." Deutschland sei über Jahrhunderte durch das Christentum, den Humanismus und die Aufklärung geprägt worden, nicht durch den Islam. „Und in diesem Sinne gehört der Islam natürlich nicht zu Deutschland."

- Der FDP-Parteichef Christian Lindner betonte im SWR-Interview der Woche, "der Islam ist eine Realität "in Deutschland. "Aber das Integrations Leitbild, das wir haben müssen, das muss basieren auf den republikanischen Werten des Grundgesetzes, auf unserer Rechtsordnung, und für die kann es keinen Rabatt geben für niemanden."

- "Das ist Wasser auf die Mühlen derer, die eben die Gesellschaft spalten wollen, die Anhängern einer Religion die Zugehörigkeit $\mathrm{zu}$ einer Gesellschaft absprechen wollen", sagte er (Abdassamad E Yazidi, Generalsekretär des Zentralrats der Muslime).

The choice of comments made by WELT journalist indicates an imbalance. There are more comments which positions Muslims as the guilty party for the current situations in Germany, namely the new Antisemitism. Muslims has no discourse acces in order to encounter the opinion stated by the choosen comment because most of the commentators are politician and expert, that tend to sided to Jews and Israel.
The macro structure in the news are strengthened by the micro level, that is the linguistics level. It can be founded in the datas that there is some lexical choice used to describe the actor in the news, namely Islam, Muslims, Jews, and Israel. Is lam and Muslims are described as a group who are related to radicalism (Radikal), anti liberal (anti Liberal), racism (Rasismus), and antisemitism (Antisemitismus). Applaying implicit sentences, the journalist try to inform that it is difficult for muslims to deal with integration issues.

(a) "Aber das Integrations-Leitbild, das wir haben müssen, das muss basieren auf den republikanischen Werten des Grundgesetzes, auf unserer Rechtsordnung, und für die kann es keinen Rabatt geben für niemanden." $\rightarrow$ it is hard for muslims to follow the German constitution. The use of modal muss in this sentence implies that there are power inequality between Germany and Muslims, so that they have a right to oblige Muslims to follow their will, i.e obey the German constitutions and rules.

(b) "Alle in Deutschland lebenden Menschen müssen wissen: Jegliche Form von Antisemitismus - von rechts wie von links - wird in unserer Gesellschaft nicht geduldet" $\rightarrow$ any form of antisemitism won't be tolerated for all people who lives in Germany. The words all people in this context include Muslims who lives in this country $\rightarrow$ antisemitism is not allowed to spread in Germany.

From (b) we can also observed that Germany stated implicitly how Jews take an important place in this country. Jews and Israel are positioned as a victim of the antisemitism caused by the migrant. Another micro strategies that apply is the granularity or the level of description written by the journalist. They prefer to use detail information to emphasize the bad side of muslims. Muslims is categorized as out group which are not a part of in group together with Germany and Israel.

\section{CONCLUSION}

The general tenor of these studies is that the coverage about Islam and Muslims is predominantly negative, stereotypical, radical, and racist. Islam is mainly covered in relation to conflict issues such as intolerance and new antisemitism. Muslims, portrayed as a homogenous entity, are often represented as the 'out group' and a threat for Germany. As most majority society Germans have little or no direct contact at all with Muslims, their image of Islam is significantly influenced and shaped by the mass Media. The negative portrayal of Muslims may serve to build or provide evidence for existing anti-Muslim attitudes. Apart from islamophobia, anti-Semitism is represented more as victim. This notion always historically attributed with the holocaust in Hitler era. Therefore the new anti-Semitism can't be tolerated.

\section{REFERENCES}

[1] M. V. Berek, Antisemitism and Immigration in Western Europe Today: Is There Any Connection?. Berlin: EVZ, 2018.

[2] T. A. Van Dijk, Handbook of Discourse Analysis. Oxford: Blackwell, 2001.

[3] J. Renkema, Introduction to Discourse Studies. Amsterdam: John Publishing Company, 2004

[4] N. Fairclough, Language and Power. England: Longman, 2001.

[5] T. A. Van Dijk, Ideology and Discourse. Barcelona : Pompeu Fabra University, 2006. 
[6] M. Foucault, The Order of Discourse in Robert Young. London: Rout ledge, 1981.

[7] N. Fairclough and R. Wodak, Critical Discourse Analysis. London: Sage, 1997

[8] T. A. Van Dijk, Discourse and Context, A Sociocognitive Approach. New York: Cambridge University Press, 2008.
[9] T. A. Van Dijk, News as Discourse. New Jersey: Lawrence Erlbaum Associates Publisher, 1988 